\title{
A MORAL ASSESSMENT OF THE POLISH ISRAELI DECLARATION FOLLOWING THE 2018 POLISH ANTI-DEFAMATION LAW
}

\author{
EYAL LEWIN \\ Department of Middle Eastern Studies and Political Science \\ Ariel University, 40700 Israel \\ E-mail address: leyal@ariel.ac.il \\ ORCID: https://orcid.org/0000-0001-5461-6634 \\ ORIT MILLER-KATAV \\ Department of Middle Eastern Studies and Political Science \\ Ariel University, 40700 Israel \\ E-mail address: oritm7@bezeqint.net \\ ORCID: https://orcid.org/0000-0002-0662-2543
}

\begin{abstract}
Aim. This paper focuses on the question to what extent the Netanyahu-Morawiecki joint declaration of June 27, 2018, was indeed a moral one. Ignoring the realpolitik versus ideal politics discourse, our goal is to find out whether solely on an ethical level one can judge the moral qualities of the political concession.

Concept. To conduct an ethical judgement process, we took the following steps: (I) A review of the Israeli narrative. (II) A review of the Polish narrative. (III) An account of some moral shortcomings in both the Israeli as well as the Polish narratives. Eventually, these steps enabled us to reach a certain moral conclusion regarding the Polish Israeli declaration.

Cognitive value. We conclude that the Polish Israeli joint declaration was indeed a moderate compromise that could enable positive forces on both sides to strengthen their national narratives - not necessarily on account of each other. Furthermore, it could also serve as a mechanism that can elevate Holocaust research as well as universal understandings of lessons that can be learnt from the darkest age of human history.

Key words: national narrative, victimhood, Polish Israeli relations, Holocaust remembrance
\end{abstract}

\section{INTRODUCTION}

n February 1, 2018, both houses of the Polish parliament adopted a law that effectively banned any accusations against Poles as collaborators with 
the Nazi crimes that were executed on Polish soil, primarily referring to the Auschwitz-Birkenau extermination camp. In its article 55 the bill read:

Whoever claims, publicly and contrary to the facts, that the Polish Nation or the Republic of Poland is responsible or co-responsible for Nazi crimes committed by the Third Reich [...], or for other felonies that constitute crimes against peace, crimes against humanity or war crimes, or whoever otherwise grossly diminishes the responsibility of the true perpetrators of said crimes - shall be liable to a fine or imprisonment for up to three years (Hattis-Rolef, 2018).

Israeli reactions to the Polish legislation were fierce. Prime Minister Netanyahu, as well as some of his ministers, condemned the bill and implied that it was a form of Holocaust denial. Israel's Holocaust Remembrance Authority, Yad Vashem, warned that the new law would violate free speech rights and could threaten Holocaust survivors as well as historians. However, throughout the weeks that followed, negotiations between Israeli and Polish officials lowered the flames. Prime Minister Benjamin Netanyahu with his Polish counterpart Prime Minister Mateusz Morawiecki led to the establishment of an official Polish group that was to deliberate with its Israeli counterparts the various controversial topics concerning the Holocaust. Hence, about five months later Netanyahu could distribute the following statement in the name of both Israeli as well as Polish governments:

Poland has always expressed the highest understanding of the significance of the Holocaust as the most tragic part of the Jewish national experience. We believe that there is a common responsibility to conduct free research, to promote understanding, and to preserve the memory of the history of the Holocaust. [...] The wartime Polish government-in-exile attempted to stop this Nazi activity by trying to raise awareness among the Western allies of the systematic murder of the Polish Jews.

[...] We acknowledge and condemn every single case of cruelty against Jews perpetrated by Poles during World War II. We are honoured to remember heroic acts of numerous Poles, especially the Righteous Among the Nations, who risked their lives to save Jewish people.

[...] We acknowledge the fact that structures of the Polish underground state supervised by the Polish government-in-exile created a mechanism of systematic help and support to Jewish people, and its courts sentenced Poles for collaborating with the German occupation authorities, including for denouncing Jews.

We support free and open historical expression and research on all aspects of the Holocaust so that it can be conducted without any fear of legal obstacles, including but not limited to students, teachers, researchers, journalists and of course, the survivors and their families, who will not be subjected to any legal charges for exercising the right to free speech and academic freedom with reference to the Holocaust. No law can and no law will change that. 
Both governments vehemently condemn all forms of anti-Semitism and express their commitment to oppose any of its manifestations. Both governments also express their rejection of anti-Polonism and other negative national stereotypes. The governments of Poland and Israel call for a return to civil and respectful dialogue in the public discourse (Israel Ministry of Foreign Affairs, Press Room, June 27, 2018).

The joint declaration was a compromise that was supposed to settle things, but the dispute proved to be anything but settled. In fact, it turned out to be the beginning of a debate over the moral dimension of the concession that has been achieved by the two leaders. Yehuda Bauer, the prominent Holocaust researcher, went as far as referring to the declaration as an act of treason (Aderet, 2018). Accordingly, Yad Vashem released a document condemning the Netanyahu-Morawiecki declaration, undermining its historic and moral validity, claiming that it consisted of historical distortions (Aderet, 2018). The whole affair threatened to deteriorate the positive relationship between Poland and Israel. We must remember that Poland and Israel hold tight international political, economic, and cultural contacts. Every year, there are more and more Israelis touring Poland and staying there. The records prove that there is a similar increase of Poles who come to Israel. Israeli entrepreneurs advance industries in Poland and their Polish counterparts participate with them in various joint ventures. Today, more than ever in the past, Israeli and Polish scientists collaborate and exchange visits (Wróbel, 1997). Furthermore, there is a revival of Jewish culture in Poland. Young Polish men and women learn Yiddish, dance Hora, and enjoy Hassidic music. This phenomenon can be found all over Poland - in Cracow, Warsaw, Lublin, and Gdansk (Horowitz, 2011). The diplomatic activities of officials on both sides were merely an attempt to maintain these good interactions and to return to the business as usual international contacts. In this sense, the responsive arguments of Netanyahu and other Israeli officials in relation to the moral accusations against the Israeli-Polish declaration stated by Bauer and by scholars of Yad Vashem was not about history or memory; rather, it was about the use of realpolitik on account of historic justice. Whereas the Israeli administration was eager to maintain positive foreign relations, the leading Holocaust historians claimed that the Israeli Prime Minister sold cheaply Jewish and universal justice.

This paper focuses on the question to what extent the mutual declaration was indeed a moral one. Ignoring the realpolitik versus ideal politics discourse, our goal is to find out whether solely on an ethical level one can judge the moral qualities of the political concession. To do so, we constructed this paper according to the following three steps: (I) A review of the Israeli narrative. (II) A review of the Polish narrative. (III) An account of some moral shortcomings in both the Israeli as well as the Polish narratives. Eventually, these steps enabled us to reach a certain moral conclusion regarding the Polish Israeli declaration. 


\section{THE ISRAELI NARRATIVE}

In the framework of Israeli collective memory, the Holocaust has developed into the major episode of Jewish history. Practically, it defines Israeli identity and has priority even over the historic event of the establishment of the state of Israel. The amount of psychological and historical studies of the Holocaust is constantly increasing. The same goes for art - novels, films, and plays. There is a growing amount of scholarly literature, and of articles by commentators in journals and in the daily newspapers. There is a clear tendency to establish new Holocaust museums and commemorative institutions. Perhaps the hallmark of the Israeli educational effort to shape the Holocaust as the central historic event is the numerical growth of youth delegations who visit every year the remains of concentration camps in Poland (Resnik, 2003).

The connection between the Holocaust and the very foundation of the State of Israel, certainly its struggle for survival at any cost, is made clear in the basic formative document of the Israeli Declaration of Independence, with which the state was established. It follows that the Holocaust is Israel's raison d'être. The Zionist logic connects the Holocaust and the establishment of the State of Israel and claims that they hold cause and effect relationships. This national logic asserts that Jewish history in the Diaspora is a representation of constant occurrences of anti-Semitism. The Holocaust, for that matter, is the outstanding symbol of anti-Semitism, which in practice has never ceased to exist (Resnik, $2003 ; 1999)$.

Connecting both realities, the Holocaust and life in Israel, gives a symbolic meaning to the difficulties one undertakes when living in Israel. This connection contrasts Jewish defencelessness during World War II with the heroic Jewish self-defence that only the Jewish state can guarantee. Additionally, this connection forms a comparison between the tragic past and the heroic present and alleviates the feeling that the risk and harshness of life in Israel are reasonably negligible. Thus, the heritage of the Holocaust harmonizes Israeli Jews with Holocaust victims (Resnik, 2003; 1999).

\section{THE POLISH NARRATIVE}

The Polish position can be cut into five major themes of self-justification: Jewish heritage in Poland, The Polish people as victims, Polish resistance and its contribution to Jewish survival, The Polish church and its roles, and The Polish righteous among the nations.

\section{Jewish heritage and history in Poland}

More than a thousand years of Jewish history in Poland included periods of tolerance, religious and cultural flourishing. Jews had lived in Poland and built their lives there as a cultural, political, moral and religious centre, where the Enlightenment and Hassidic Jewish movements had grown (Netzer, 2001; Davidovitch \& Lewin, 2019; Lewin, 2018). 
From the $10^{\text {th }}$ century to the $12^{\text {th }}$ century, the first Jewish merchants and artisans settled in Poland. They were harassed and expelled from Western Europe, so escaping to the east they found refuge under the Piast and Jagiellonian reigns. Jews were usually barred from abiding under the jurisdiction of the municipal authorities, but instead, they had a special status and were subject directly to the national authority - the king or the duke. This enabled Jews to achieve influential positions in business-related life, becoming traders, money lenders, tax collectors, and innkeepers.

Between 1569 and 1795, in the political formation of the Polish-Lithuanian Commonwealth, Jews prospered. In particular, the $16^{\text {th }}$ and $17^{\text {th }}$ centuries are counted as the Golden Age of Jewish life in Poland. The Jews had a restrained autonomy and they succeeded economically. In those years, Jewish culture enjoyed prosperity - Talmudic academies and learning centres were launched, and Jewish literature, both secular as well as religious, increased immensely. Indeed, this era in Poland is frequently counted as the Paradisus Judaeorum [Jews' Paradise].

From the late sixteenth century to the end of the eighteenth century, an autonomous Polish Jewish governing establishment acted: Va'adArba Ha-Aratzot [Council of the Four Lands]. This was a council counting delegates from the various Jewish communities, and it developed into a central body of Jewish self-ruling. It was officially recognized by the king and was eventually the only Jewish public organization of this kind throughout the whole history of Jewish Diaspora.

In 1918Poland regained its independence and the new constitution announced legal equality to all Polish citizens. An unprecedented blossom of Jewish culture took place in all fields of life, with an ascending growth and development of Jewish formal and informal education, youth movements, sports clubs, theatre, cinema, literature, and a great variety of Jewish journals and newspapers. By the 1930s, the world Jewish population amounted to approximately 15 million. Four million Jews lived in the United States, 3.5 million in Poland, and 2.7 million in the Soviet Union. In Poland, Jews formed slightly above 10 percent of the population; however, they counted about 50 percent of the lawyers in the country. Concurrently, over 30 percent of all the doctors in the Capital of Warsaw were Jews. Also, 25 percent of all university students in Poland were Jews. Hence, to summarize at least one thousand years of Jewish existence in Poland, undoubtedly this country and its population incorporated the Jews embraingly (Bergman et al., 2011; Lehrer, 2010; Rubinstein, 2015; Davidovitch \& Lewin, 2019; Lewin, 2018).

\section{The Polish people as victims}

The Polish people underwent agonizing experiences under Nazi occupation. The Germans exiled large numbers of Poles to settle in the Generalgouvernement [the General Administration], and the areas from which they were evacuated were to become German residence. The Nazis deported to Germany hundreds of thousands of Poles to utilize them as forced labour 
in the production of weapons and in agriculture. Many Polish people who were transferred and enslaved died due to poor hygiene and reduced nutrition. Throughout World War II, Poland suffered food, fuel, and medication shortages, which led to a significant increase in mortality rates. Additionally, there were hundreds of thousands of Polish people who fell victim to the Nazi atrocities that characterized the German occupation (Noakes \& Pridham, 1990; Lukacs, 1989).

Whereas the cruelty of the Nazi occupation is common knowledge, rarely do we hear about the way the Soviets crushed Poland. In 1940, using the efficient units of the NKWD, the Soviet authorities started mass deportation of Poles to the depth of Russian Siberia, where the expatriates were to work as slaves. The Polish deportees suffered weeks of trafficking in cattle cars, and upon their arrival in the gulags were put into horrible living conditions. Accordingly, the mortality rate jumped, and particularly the old, the young and the sick died soon.

Any discussion concerning Polish responsibility for atrocities exercised within its conquered land cannot ignore the fact that Germany's control of Poland was in the form of forcing Poland into debellatio, that is - subduing it and putting an end to any potential struggle by means of complete destruction. Debellatio meant disintegrating all the Polish national institutes and making sure that none of its allies continued to challenge German military on its behalf (Benvenisti, 2012). Although Poland had never officially surrendered, in practice - it ceased to exist legally and politically. The Germans as occupiers assumed the right to rule the country and its people. In order to fully accomplish debellatio, the Nazis initiated a systematic elimination of the Polish elites in the broad sense, by killing thousands of them, including the intelligentsia and professions such as high army officers, doctors, businessmen, priests and anyone suspected to be an enemy of the Reich (Bogner, 2000). The Polish government was exiled to London, where it tried to do anything that was in its power to serve and represent all of the Polish people, their rights and needs under the impossible conditions, regardless of their religion (Noakes \& Pridham, 1990; Lukacs, 1989).

Most of the non-Jewish Polish victims of the Nazi occupation died of starvation, malnutrition, and consequently - illness. Others were executed, either on their terrifying journeys to the concentration camps or encountering SS units in the cities or villages all over Poland. Many Polish people died in labour camps and in concentration and death camps. Noteworthy, the earliest non-German prisoners that inhabited Auschwitz were non-Jewish Poles, and they formed a majority among the prisoners until the organized slaughter of Jews began there - as late as 1942. In fact, the first exterminations by gas in Auschwitz were exercised on some 300 Poles and 700 Russian POWs (Noakes \& Pridham, 1990; Lukacs, 1989; Steinlauf, 1997).

In addition to the account of the suffering of the Polish people under Nazi occupation, it is important to mention that Poland was actually the first state that opposed Hitler's demands, and more importantly - Poland was the first 
country to stand against his aggression and to attempt to stop it. In contrast with other European countries, there was never a Quisling among the Polish leadership nor a Vichy form of governance. There was never any Polish unit that fought on behalf of the Third Reich or that acted as an auxiliary force serving the German cause. The Polish people insisted to fight alongside the allied forces from the first day of World War II when they were betrayed by the Ribbentrop-Molotov pact. Additionally, inside Poland, constant activity of armed resistance was widespread and never ceased throughout the war (Michnik, 2014).

\section{Polish resistance as a framework for Jewish survival}

In spite of the total annihilation of the Polish state, the Polish people had their fair share in fighting against Germany in various structures, and most importantly, for our matter - these frameworks were not only organizations that fought Germany but also ones that enabled Jews to save themselves and their families. In this sense, resisting Nazi occupation went together with protecting Jews and enabling them to survive.

When Nazi Germany attacked the USSR on June 22, 1941, an amnesty was declared in the Soviet Union, and all the Polish citizens were released from the gulags. Wladyslaw Anders, the Polish General who was captured by the Soviets two years earlier, was now discharged from the Soviet prison in Moscow and founded the Armia Andersa. This was a Polish force loyal to the exile government in London. The army, annexed to the western allies, fought successfully on the Italian front and moved to Persia as an occupying force. Among its recruits were thousands of Jews who sought the way to free themselves from forced labour camps and leave the Soviet Union. In fact, the Soviet authorities approved of the emigration of around 24,000 Polish citizens together with the Armia Andersa. This group included roughly 1000 Jewish children, many of them orphans, and approximately 800 Jewish adults. The families of thousands of Jewish soldiers joined the army on their journey to the Middle East, and upon arriving in Israel many soldiers defected and remained there as illegal immigrants. Others immigrated to Israel with the disbanding of the army in 1947 (Levin, 1978; Gutman, 1978; Azrieli, 1999; Ginzburg, 1982).

Another platform for activity against the German occupation was the Armia Krajowa, an inclusive Polish underground fighter organization that had united a number of other Polish organizations. It fought against the German forces in Poland. The organization assisted the Jewish underground in the belligerent organization against the Nazis by providing weapons and grenades. One of its most familiar actions was the support of the Jewish underground in the uprising of the Warsaw ghetto and then, two years later, the initiation of the Polish uprising against the Germans. Many of the Jews who fought within this organization reached high positions and some of them took important official posts, military, and civil ones, in the communist state that was formed after the war (Michelson, 2009; Cohen, 1981). 


\section{The Polish Church}

By mid-1942 most of the pastors' activities focused on hiding Jewish children in monasteries and helping refugees from ghettos that had been liquidated. There is evidence that there were contacts between priests and Catholic Poles from Jewish origin who were locked in various ghettos. Sometimes the church members hid Jewish refugees in their churches and helped them to get along on the Arian side, providing them with food and fake certificates and identities. In certain cases, it was onetime assistance and in others - a long-term help. The church took part in hiding individuals as well as whole families, children and babies in secret places, buildings, foster Polish families and in the churches and monasteries. Many church members joined the activities of the Jewish Help Council (Żegota). It was established in 1942 with the help of Catholic associations. The organization operated in all the areas of the General Gubernman, but mainly in the major cities: Warsaw, Krakow, Lvov, Vilnius.

During the German occupation over 3,000 church members were murdered by the Nazis for suspicion of helping Jews. The members of the Catholic Church suffered persecution and punishment every step along the way, using the framework of collective punishment. The common reason for detention included activity in the underground, violations of orders and other anti-German statements and violations of government regulations (Libionka, 2000).

\section{Polish righteous among the nations}

According to the Yad Vashem Institute, Poland is where there was the largest number of righteous among the nations both in ultimate figures $(6,992)$ as well as in comparison to other nations. Admittedly, during World War II, Poland included more Jews than any other country in Europe; yet in Poland, there was also the largest number of non-Jews who were executed for trying to save Jews and help them to survive. Additionally, Poland was exceptional in being the only Eastern European country that constructed an underground organization aimed at saving Jews. Zegota, a codename for the Council to Aid the Jews, was started by Zofia Kossak-Szczucka, who was a Polish writer. The Council included democratic Catholic activists and Jews and non-Jews from diverse political streams. Notwithstanding many political differences, they were driven by an urge to oppose the atrocities committed by the Nazis. Zegota supplied the Jews with false documents and with money and located for them secure sites where they could hide. We must remember that there was an immediate, in practice - an automatic death sentence for anyone who was caught hiding Jews (Kurek, 1997). On the political level, Zegota put pressure on the Polish Government in Exile to encourage the Polish people to assist Jews and to save as many of them (Paulsson, 2002).

Jan (Kozielewski) Karski was a Polish diplomat who joined the Armia Krajowa and served secretly the exiled Polish government. He tried to raise awareness all over the world about the horrors that the Jews were going through in Poland and in other European countries. He even reached Winston Churchill and Franklin Roosevelt, but his warnings met indifference. His case is very 
different from other righteous among the nations in the sense that he did not actually save someone personally during the war; however, he put himself at high risk by trying to save as many Jews as he could, and he did that as a representative of Poland (Wood \& Janowski, 1994).

In terms of image and historic narration, misconception gives other counties in Europe a relative advantage over Poland as more friendly countries and as ones whose citizens did more to save Jewish lives. This distortion is even greater considering the well-known fact that in Nazi-occupied Eastern Europe assisting Jews could cause the death of one's whole family, not just the rescuer himself, whereas in Western Europe punishing was much more lenient (Wood \& Janowski, 1994).

\section{Some Moral Cracks in the National Narratives}

Both Israeli and Polish National narratives concerning the World War II experience have some ethical flaws, which we shall now put forward.

\section{Ethical Shortcomings within the Israeli Narrative}

As earlier mentioned, the Holocaust is used as one of the justifications for Zionism, and the very proclamation of the state outlines the Holocaust as partly imperative in modern history for re-building a homeland in Israel. Having said that, we also put forward, in the framework of our role as researchers, a contradicting interpretation that claims for ethical shortcomings not only within the Polish narrative but also within the Israeli one. This other voice claims that the Israeli stand is not entirely clean of national manipulation; it accuses past and present Jewish leadership of manipulating historical circumstances. Whether right or wrong, this attitude can be criticized, but should not be ignored - least of all in a paper that analyzes narratives.

According to the challenging version, the security arguments supporting the continuation of Israeli control over the territories taken in the course of the 1967 war are too often rationalized by relying on the Holocaust and its lessons (Lewin, 2018). History has the tendency to repeat itself, and considering the viciousness of the Arab enemies, let alone their historic admiration of Nazism, Israel can never risk having overly vulnerable borders. Abba Eban, Israel's leading diplomat of all time, is considered to have coined the term Auschwitz borders, referring to the non-defendable lines from which Israel was attacked in 1967 and from which he claimed Israel should never withdraw (Der Spiegel, November 5, 1969, cited in The Jerusalem Post, August 18, 1995). Additionally, if exchanging land for peace endangers Israel and if Israel - challenged by a potential new Holocaust - should never take chances, those who advocate a territorial compromise resemble the well-intentioned naïve Western states that pushed Czechoslovakia to give up the Sudetenland. Thus, any pressure on Israel to negotiate land for peace treaties might eventually end up pushing the Jews off a cliff (Landman, 2010).

The linkage of Zionism, together with Israel's security, and the lessons to be learned from the Holocaust, can vividly be heard in Prime Minister Binyamin 
Netanyahu's addresses during the 2010s at the AIPAC convention, at the UN assembly and in the American congress in 2015 - taking Iran to be the new Third Reich.

\section{Ethical Shortcomings within the Polish Narrative}

The Polish accounts of the Holocaust are considered by various historians as driven by denial, mainly because there seems to be no symmetry between the destiny that befell Jewish Poles, with a death rate of 90 percent, as opposed to the 10 percent death rate of non-Jewish Polish people who were supposedly victims of the same Nazi atrocities (Michnic-Coren, 1999).

Additionally, it is hard to overlook the circumstances of a right-wing led Poland that during the early 1930s regarded Nazi Germany as a legitimate political ally against the Soviet threat coming from the East. Moreover, one cannot disregard the fact that under this tendency, Poland also started to foster the Nazi model. There was a sharp increase in pogroms in Polish towns and villages, together with rising riots at the university campuses. Campaigns against Jewish trade in Poland were supported by legal and official discriminatory actions. As a result, thousands of Polish Jews fled to the West, in particular - Holland, France, and Belgium, and others left for Palestine. All this raises a reflection about the place of the Polish people in this chapter of world history - whether they were victims, bystanders, or perpetrators.

In a search for more insights concerning this reflection, this essay investigates the diary of Calel Perechodnik (Perechodnik, 1996). The diary writer was a Polish Jew who died in Otwock, a small town near Warsaw. All of Otwock's eight thousand Jews were murdered. Perechodnik testified that he met non-Jewish Polish people who helped Jews and were undoubtedly motivated by an unselfish drive to assist. His proof for this was the very fact that he was still alive to write a diary as late as 1944 . As he pointed out, without the help of Catholic Poles he would not reach that point in time. Nevertheless, Perechodnik also asserted that low-class townspeople, as well as peasants, realized that getting rid of the Jews was an opportunity to improve their economic positions, an opportunity that was unlikely to ever come again. Now, one could practically loot and evade punishment; one could steal, kill - directly or indirectly - and inherit the murdered without being responsible for any wrongdoings. The blame, if ever was to be put on someone, was the Germans'. Consequently, countless Jews died at the hands of Polish townsfolk and farmers. Wherever there was an aktion, the same collective behavioural pattern took place: the ghetto was surrounded by a mob that launched a ceremonial hunt on Jews.

Another moral criticism that Perechodnik raises is against the Polish leadership. He asserts that by not being active enough and determined to assist Jews, their passiveness on this subject permitted a collective feeling that Jewish blood was in fact worthless. In all the Polish leadership's communique and announcements, that spoke about Nazi atrocities, even in those where compassion for the Jews was expressed, it was clearly noted that the best of Jews were those who in the first place before the war started, left for Palestine. According to 
Perechodnik, all it really took to change the atmosphere was one sole notification in the daily press, that would announce that delivering Jews to the Germans was a crime and would be punished severely once the war ended. The Polish leadership, however, refrained from expressing solid opinions about the need to defend Jews or to assist them, and the results were accordingly (Perechodnik, 1996).

It seems that one of the most significant landmarks in the debate over the Polish behaviour throughout World War II is the neglected story of Jedwabne, that was disremembered and overlooked for decades before emerging suddenly into public awareness at the beginning of the 2000s. Jedwabne is a small town in northeast Poland, where Jews started to live as early as 1736 with the rise of the Polish monarchy. When World War II broke out, Jews comprised about 60 to 70 percent the 2000 people populating Jedwabne. When the war started, eastern Poland was occupied by the Soviets, who terrorized the population and deported many Polish citizens to Siberia. The Soviet occupation of Jedwabne ended when the Germans arrived on June 22, 1941, Nazi invasion of the USSR. Rumors that the Jews benefitted from the former Soviet occupation and cooperated with the Russians propelled anti-Jewish sentiments throughout the whole region. July 10, 1941, about three weeks after the takeover of the Germans, Marian Karolak, the mayor of Jedwabne, and the German gendarmerie ordered the roundup of all the town's Jews, including Jews from surrounding towns who sought refuge in Jedwabne (Gross, 2001; Davidovitch \& Lewin, 2019).

Anna Bikont, one of the Polish eyewitnesses, was ten years old when she watched how her townsfolk flocked their Jewish neighbours into a large barn. Schoolboys mocked their Jewish peers, harassing them and hounding them toward death. Jewish mothers held their babies tight, trying to protect them from the blows. It took only minutes before nearly all Jedwabne's Jews, hundreds of them, from babies and children to old people, were burned alive. Sixty years later, Bikont, who became a reporter for the Gazeta Wyborcza, the liberal Polish newspaper, interviewed other witnesses, but also perpetrators and survivors of the Jedwabne massacre. She investigated similar mass killings of Jews in the neighbouring towns of Radzilow and Wasosz (Bikont, 2016; Davidovitch \& Lewin, 2019).

The massacre of the Jedwabne Jewish community was not the only event of its kind. In the summer of 1941, after the German invasion and the Soviet retreat, many acts of violence took place in the Polish region of Łomża and Białystok. Polish people assaulted Jews with the encouragement of the Nazi bystanders (Gross, 2001). The IPN [Institute of National Remembrance - Commission for the Prosecution of Crimes against the Polish Nation] was established in 1998 by the Sejm and started acting in the middle of 2000. An investigation carried out by the IPN showed that events like the Jedwabne massacre also took place in at least 23 other Polish localities, counting Bielsk Podlaski, Choroszcz, Czyżew, Goniądz, Grajewo, Jasionówka, Jedwabne, Kleszczele, Knyszyn, Kolno, Kuźnica, Narewka, Piątnica, Radziłów, Rajgród, Sokoły, Stawiski, 
Suchowola, Szczuczyn, Trzcianne, Tykocin, Wasilków, Wąsosz, and Wizna (Davidovitch \& Lewin, 2019).

\section{Conclusion: A Moral Examination of the Joint Declaration}

A general definition of compromise assumes that compromise is a mode of conflict resolution in which parties in dispute decide to remove or to cut some of their original claims. A compromise that puts an end to a dispute is clear and well-defined, and it suggests recognition and acceptance of the other (Roy, 1990). Thus, compromise is based on moral foundations and is unsurprisingly respected as a positive event.

There are two contradicting yet balancing attitudes toward compromise. The first is the process attitude that relates to the forces at work that shape the concluding compromise settlement. The second is the final-status attitude, that analyzes the outcome and concentrates on the agreement that was accomplished through the process (Golding, 1979). Taking the first attitude, compromise is connected to a specific procedure intended to end or to suspend the divergence. However, the second attitude does not inquire how the settlement was reached and focuses only on its results. This essay preaches, so to speak, to adopt the final - status attitude, to view the outcomes of compromise as the best possible results.

We can sympathize, however. With proponents of the process attitude. The usual view is that compromise is fair, mainly because the other options may lead to aggression. If the violent alternative takes place, physical strength is bound to rule and fairness will become unconnected. However, compromise is not necessarily always fair (Jones \& O'Flynn, 2012). If we assume that truth is not relative and that for every event there is only one objective narration, the risk of reaching unfair results through compromise increases. This can be illustrated with a hypothetic episode. Allen claims that he lent his buddy Benny $\$ 100$, but according to Benny such an incident has never happened. After a long debate, the two pals turn to David, who in the name of good spirits and friendship persuades them to compromise. However, any Solomonic Judgment on David's side, to reconcile and ensure future friendship between Allen and Benny might be contaminated by an immoral decision. For example, supposing that to finish the dispute they settle on $\$ 50$ that Benny will pay Allen. Since the outcome is a renewal of Allen and Benny's comradeship, the settlement seems to be honest. However, there is no way that such a compromise can really be just. If Allen is a liar, then there is nothing fair in Benny's $\$ 50$ payment to him; in fact - it only proves how lying pays. If Benny is a liar, on the other hand, then there is nothing fair in ordering him to return only half of what he borrowed. Since there can only be one truth, and therefore - just one of them is morally right, any proposed settlement in its essence unethical.

When a dispute is overvalued the compromise suggests that upon negotiating at least one of the sides deserted, at least partly, measures of truthfulness (Kuflik, 1979). Martin Benjamin (1990) expresses this as a part of a paradox: 
Were we never to accept political compromise on matters of ethical conviction, we would cut ourselves off from large numbers of our fellow humans; were we always to accept it, we would become alienated from ourselves (Benjamin, 1990, 3).

Indeed, the public sphere is full of cases where political disputes are over moral issues, such as abortion, gun control, or assisted death just to name a few. Also, questions of public priorities (for example - taxation, minimum wage, medical care) are topics where moral dilemmas are involved. Because these ethical disagreements are the meeting points of contradicting principles, they are often intractable. However, the commonly held view is that we should do our absolute best to reach a compromise even in cases of disagreement (Kappel, 2018). On the other hand, if the public dispute is over ethical matters then from a moral point of view there is no room for compromise. Surely the sides can eventually reach a settlement, but that will result from pragmatic and instrumental considerations such as the need for ongoing collaboration or maintaining stability (May, 2005).

Despite this analysis, one ought to leave a chance for moral compromise after all. Ethical compromises can be reached when the parties in dispute are not demanded to alter their integrity, and at the same time within their spectrum of options, there is no contradiction with any of their moral principles. Additional circumstances for moral compromises are when honest deliberations lead parties to modify their views and to foster some of their opponents' perceptions (Kappel, 2018). This attitude overlaps with John Rawls' concept of public reason - a political comprehension of justice that should administer citizens in a democratic environment (Rawls, 1996; Larmore, 2003).

Reading into the Netanyahu-Morawiecki joint declaration, particularly after reviewing both Jewish and Polish narratives, the gaps seem to diminish. The declaration clearly emphasizes the sufferings that both nations have undergone and the condemnation of any anti-Semitic, or - for that matter, any anti-Polonistic stereotype. The declaration calls for civil and respectful dialogue in the public discourse.

It is true that the Polish government takes responsibility for preserving the Polish national narrative of constant struggle against powerful invaders. In the context of World War II, this is done by emphasizing the heroism of those who resisted Nazi occupation and those who rescued Jews. From a strictly Polish point of view, the Polish people too have experienced a huge loss, just like the Jewish people; six million Polish civilians have been murdered during the war, half of them were Polish Jews and the other half were Polish non-Jews. Poland is weeping over her sons and daughters; the pain, goes the claim, is the same pain. However, the construction of the narrative is not only a Polish habit; it is universal, and Israel is no exception.

As part of the internal clashes of rival political groups in Israel, the Israeli Right-Wing underground organizations that preceded the state and the political parties were scorned by the Zionist Socialist dominant leadership. It was a political leadership that took control over national collective memory and 
shaped it one-sidedly. Accordingly, the Armia Krajowa, the dominant Polish resistance movement was ignored in schoolbooks, whereas the corresponding Polish leftist organization, the smaller Armia Ludowa, that was formed only in 1944, was crowned as the only Polish underground organization and was the leading partisan group that was mentioned in Israeli history books. This is merely an example of the many subtleties in which narratives, even those concerning the Holocaust, reflect not just international relations politics but also domestic disputes. Indeed, even the reactions in Israel to the Netanyahu-Morawiecki joint declaration are not detached from the ongoing debates between Prime Minister Netanyahu's supporters and opponents.

For Israelis, relating to the Polish narrative demands a measure of understanding complex situations. The Polish nationalistic right refused to collaborate with the Nazis, in contrast to the habit of right-wing movements elsewhere in Europe. However, the same Polish nationalistic right was also anti-Semitic. This creates a certain confusion because different characteristics that are supposed to be neatly divided into different drawers seem to get mixed suddenly. This complex gets even worse when history studies reveal the phenomenon of Polish anti-Semites who fought bravely against Hitler and were active in rescuing Jews in spite of the fact that they were risking a lethal punishment. Indeed, the Polish case study represents a unique historic paradox: in occupied Poland, a person could be at the same time an anti-Semite, a fighter in the lines of the resistance movement or with the Partisans, and a rescuer of Jews (Michnik, 2014). The fabricated contrast between a coherent group of Right Polish anti-Semites and an opposing consistent social group of Leftist Polish anti-Nazis was constructed to serve the domestic quarrels of Israeli politics. This classification between the totally negative social factors and the totally positive social elements enabled a simple choice between friend and foe. However, the simplistic typology torpedoes the ability to poke into the complexities of Polish reality (Lewin, 2014).

Issues concerning the Israeli-Polish relationship and likewise the Jewish-Polish bonds have not been debated publicly and responsively in Israel, except for the domestic debate that took place during the second half of 2018 following the Polish law and the various reactions to its legislation. Somewhat typical for Israeli internal political disputes, it never reached any consensual conclusions. The discourse in Poland did not prove to be any more productive, portraying just the tip of an iceberg and giving an example for decades-long European culture struggles over identity, nationalism, and history (Ray \& Kapralski, 2019). The distance between Warsaw and Jerusalem seemed, for a while to extend long beyond the four thousand kilometers physically separating the two capitals.

At the same time, the renewal and revitalization of Jewish heritage in Polish cities (Horowitz, 2011) indicates that the Polish people are eager to cooperate with Israelis and are willing to relate to historical events in an unprecedented manner. If Israelis really wish to stimulate common worldwide values, there is a need for a substantial meeting with the Polish people. Only such 
encounters have the capacity to establish a path to recognition, acceptance, and understanding of others (Zimmerman, 2003; Davidovitch \& Soen, 2015). Our conclusion, therefore, is that the Polish-Israeli joint declaration was not only a moderate compromise that could enable positive forces on both sides to strengthen their national narratives - not on account of each other - but it could also serve as a mechanism that can elevate Holocaust research as well as universal understandings of lessons that can be learnt from the darkest age of human history.

\section{REFERENCES}

[1] Aderet, O. (2018). With Holocaust Declaration, Netanyahu and Polish MP Use History for Political Needs. Haaretz, July 11, 2018. July 11, 2018, from https:/ / www.haaretz.com/israelnews/.premium-netanyahu-in-warsaw-saying-poles-collaborated-with-nazis-never-gotanyone-sued-1.6937839.

[2] Aharony, M. (2019). Why Does Hannah Arendt's "Banality of Evil” Still Anger Israelis? Haaretz, May11,2019. RetrievedMay11,2019,fromhttps://www.haaretz.com/israel-news/.premium. MAGAZINE-why-does-hannah-arendt-s-banality-of-evil-still-anger-israelis-1.7213979.

[3] Azrieli, D. (1999). One Step Ahead: Memoirs, 1939-1950. Yad Vashem Studies, 23, 77-83.

[4] Benjamin, M. (1990). Splitting the Difference: Compromise and Integrity in Ethics and Politics. Lawrence, KS: Kansas University Press.

[5] Benvenisti, E. (2012). The International Law of Occupation. Oxford, UK: Oxford University Press.

[6] Bergman, E., Czerwonogora K., Gebert K., Hannush V., Lieberman H., Matuszewka M., \& Sajdak A. (2011). 1,000 Years of Jewish Life in Poland. Belmont, CA: Taube Foundation for Jewish Life and Culture.

[7] Bikont, A. (2016). The Crime and the Silence: Confronting the Massacre of Jews in Wartime Jedwabne New York, NY: Farrar, Straus and Giroux.

[8] Bogner, N. (2000). At the Mercy of Strangers: The Rescue of Jewish Children with Assumed Identities in Poland. Jerusalem: Yad Vashem.

[9] Cohen, L. (1981). Jewish Fighters in the War against the Nazis,. Tel Aviv:Poalim Library.

[10] Davidovitch, N., \& Lewin, E. (2019). The Polish-Jewish Lethal Polka Dance. Journal of Education, Culture and Society, 2 15-31.

[11] Davidovitch, N., \& Soen, D. (2015). The Trip Experience - Poland and the Polish People as Perceived by Israeli Youth in Light of their Trips to the Death Camps. In: N. Davidovitch, \& D. Soen (Eds). Shoa and Experience - A Journey in Time (pp. 1-25). Boston,.MA: Academic Studies Press.

[12] Gerstenfeld, M. (2000). Wartime and Postwar Dutch Attitudes toward the Jews: Myth and Truth. Jewish Political Studies Review, 12 (1,2), 55-95.

[13] Ginzburg, T. (1982). Anders Army. Jerusalem: Yad Vashem.

[14] Golding, M. P. (1979). The Nature of Compromise: A Preliminary Inquiry. In: J. R. Pennock \& W. Chapman (Eds.). Compromise in Ethics, Law and Politics, Nomos (pp. 3-25). New York, NY: New York University Press

[15] Gross, J. T. (2001). Neighbors: The Destruction of the Jewish Community in Jedwabne, Poland. Princeton, NJ: Princeton University Press.

[16] Gutman, I. (1978). Jews in the Anders Army in the Soviet Union., Yad Vashem, 18, 171-213.

[17] Jones, P., \& O'Flynn, I. (2012). Can a Compromise Be Fair? Politics, Philosophy E Economics, 12(2), 115-135.

[18] Hattis-Rolef, S. (2018). Poland and Israel: National Narratives and Myths. Jerusalem Post. Retrieved July 15, 2018 from https://www.jpost.com/opinion/ think-about-it-poland-and-israel-national-narratives-and-myths-562587.

[19] Horowitz, G. (2011). The Other Poland. Israel Hayom, November 27, 2011 [Hebrew].

[20] Kappel, K (2018). How Moral Disagreement May Ground Principled Moral Compromise. Politics, Philosophy E Economics, 17(1),75-96. 
[21] Kuflik, A. (1979). Morality and Compromise. In: J. R. Pennock, \& J. W. Chapman (Eds.). Compromise in Ethics, Law and Politics, Nomos (38-65). New York, NY: New York University Press.

[22] Kurek, E. (1997). Your Life Is Worth Mine: How Polish Nuns Saved Hundreds of Jewish Children in German-Occupied Poland, 1939-1945. New York, NY: Hippocrene Books.

[23] Landman, S. (2010). Barriers to Peace: Protected Values in the Israeli-Palestinian Conflict. In: Y. Bar-Siman Tov (Ed.), Barriers to Peace in the Israeli-Palestinian Conflict (pp. 135-177). Jerusalem, Israel: The Jerusalem Institute for Israel Studies.

[24] Larmore, C. (2003). The Cambridge Companion to Rawls. Cambridge, UK: Cambridge University Press.

[25] Lehrer, E. (2010). Can There Be a Conciliatory Heritage? International Journal of Heritage Studies, 16, 269-288.

[26] Levin, D. (1978). Anders Soldiers, Et- Mol, 18(5), 109.

[27] Lewin, E. (2014). Ethos Clash in Israeli Society. Lanham, MD: Lexington.

[28] Lewin, E. (2018). A Swastika in the Temple. In: N. Davidovitch, E. Lewin, \& R. A. Cohen (Eds). Post-Holocaust Studies in Modern Context. Hershey, PA: IGI Global.

[29] Libionka, D. (2000). The Catholic Church in Poland and the Holocaust, 1939-1945. Jerusalem, Israel: Yad Vashem Resource Center.

[30] Lukacs, R. C. (1989). Out of the Inferno: Poles Remember the Holocaust. Lexington, KY: University Press of Kentucky.

[31] May, S. C. (2005). Principled Compromise and the Abortion Controversy. Philosophy and Public Affairs, 33(4), 317-348.

[32] Michelson, B. (2009). Jewish Soldiers in the Polish Army During WW II, Armor, 33, 16-21.

[33] Michnik, A. (2014). The Trouble with History: Morality, Revolution and Counterrevolution. New Haven, CT: Yale University Press.

[34] Michnic-Coren, J. (1999). The Troubling Past: The Polish Collective Memory of the Holocaust. European Bibliography of Slavic and East European Studies, 29(1-2), 75-84.

[35] Netzer, S. (2001). Between Anti - Jewish Legislation and Integration: Poles and Jews, 1918 1939, Bishvil Hazikaron, 40, 13-21.

[36] Noakes, J., \& Pridham, G. (1990). Nazism: A History in Documents and Eyewitness Accounts, 1919-1945. New York, NY: Schocken Books.

[37] Paulsson, G. S. (2002). Secret City: The Hidden Jews of Warsaw, 1940-1945. Suffolk, UK: Yale University Press.

[38] Perechodnik, C., F. Fox - trans. (1996). Am I a Murderer? Testament of a Jewish Ghetto Policeman. Boulder, CO: Westview.

[39] Ray, L. \& Kapralski, S. (2019). Introduction to the Special Issue - Disputed Holocaust Memory in Poland. Holocaust Studies, 25(3), 209-219.

[40] Rawls, J. (1996). Political Liberalism. New York, NY: Columbia University Press.

[41] Resnik, J. (1999). Particularistic vs. Universalistic Content in the Israeli Education System. Curriculum Inquiry, 29(4), 485-511.

[42] Resnik, J. (2003). "Sites of memory" of the Holocaust: Shaping national memory in the education system in Israel. Nations and Nationalism, 9(2), 297-317.

[43] Roy, J. (1990). Compromis. In: A. Jacob (Ed.). Encyclopedie Phylosophique Universelle, Vol. II: Les Notions Phylosophiques Paris, France: PUF, 330.

[44] Rubinstein, E. (2015). Witness: Passing the Torch of Holocaust Memory to New Generations. Toronto, Canada: Second Story Press and March of the Living.

[45] Steinlauf, M. C. (1997). Bondage to the Dead: Poland and the Memory of the Holocaust. New York, NY: Syracuse University Press, 1997.

[46] Wood, E. T. \& Janowski, S. M. (1994). Karski: How One Man Tried to Stop the Holocaust. London, UK: John Wiley \& Sons.

[47] Wróbel, P. (1997). Double Memory: Poles and Jews after the Holocaust. East European Politics and Societies, 11:,560-574.

[48] Zimmerman, J. (2003). Contested Memories: Poles and Jews during the Holocaust and its Aftermath. New Brunswick, NJ: Rutgers University Press. 